Human and Animal Health

Vol.60: e17160179, January-December 2017 http://dx.doi.org/10.1590/1678-4324-2017160179 ISSN 1678-4324 Online Edition

\title{
Assessment of the Toxicity of Sub-chronic Low and High Doses of the Bio-insecticide Spinosad on the Liver, Kidney and the Cerebellum in Male Albino Mice
}

\author{
Sabry A El-Naggar ${ }^{1,2}$, Hala Eltantawi ${ }^{3,4}$, Mahrous A Ibrahim ${ }^{5,6}$, Abeer Alm-Eldeen ${ }^{1}$. \\ ${ }^{I}$ Tanta University - Zoology Department, Faculty of Science, Tanta, Egypt; ${ }^{2}$ Aljouf University - Biology \\ Department, College of Science, Sakaka, Aljouf, Saudi Arabia; ${ }^{3}$ Ain Shams University Faculty of Science - Zoolgy \\ Department, Faculty of Science, Cairo, Egypt; ${ }^{4}$ University of Dammam - Biology Department, College of Science \\ Dammam, Saudi Arabia; ${ }^{5}$ Suez Canal University - Forensic Medicine \& Clinical Toxicology Department , Faculty \\ of Medicine, Ismailia, Egypt; ${ }^{6}$ Aljouf University- Forensic Medicine \& Clinical Toxicology Department, College of \\ Medicine, Sakaka, Aljouf, Saudi Arabia..
}

\begin{abstract}
Spinosad (SPD) is a highly selective insect control product. However, it was reported that SPD has toxicity toward other non-target organisms. This study was conducted to address the toxic effect of two sub-chronic low and high doses; 35 and $350 \mathrm{mg} / \mathrm{kg}$ SPD on some biochemical, histological and immunohistochemical parameters of the liver, kidney and cerebellum. Thirty-six male Swiss mice were divided into three groups of 12 mice each; first group (G1) served as a control, second group (G2) received a low sub-chronic dose of SPD that is equal to $35 \mathrm{mg} / \mathrm{kg}$, and third group (G3) received a high sub-chronic dose of SPD that is equal to $350 \mathrm{mg} / \mathrm{kg}$. The results showed that mice which were received $350 \mathrm{mg} / \mathrm{kg} S P D$ showed a significant decrease in the body weight and a significant increase in their relative kidney and spleen weights. They also showed a significant increase in alanine aminotransferase (ALT), triglycerides and urea levels. Histopathological examination showed cytoplasmic degeneration and cell necrosis in the liver and kidney. Immunohistochemical examination showed that cerebellum illustrated several neurodegenerative changes and a down-regulation of synaptophysin-Syp. In conclusion, exposure to a high dose of $S P D$ that is equal to $350 \mathrm{mg} / \mathrm{kg}$ could cause a marked toxicity on the liver, kidney and cerebellum in male albino mice.
\end{abstract}

Key words: Bio-insecticide; Spinosad; toxicity; sub-chronic; biochemical; histological; immunohistochemical; alterations

\footnotetext{
*Author for correspondence: sabry_elnaggar@yahoo.com
} 


\section{INTRODUCTION}

Spinosad (SPD) is a highly selective bio-insecticide that derives from the aerobic fermentation of the naturally occurring Actinomycete bacterium, Saccharopolyspora spinosa ${ }^{1,2}$. It is composed of two active components, spinosyn $A$ and spinosyn $\mathrm{D}^{3}$. Human exposure to SPD could occur by direct consumption of food and water that contain low residues of SPD or by non-dietary routes of exposure. The highest concentrations of SPD residues in the tissues were identified in liver, kidney and lymph nodes ${ }^{4}$. Furthermore, it was reported that the rate of decline is slow and results in higher concentrations of SPD in the thyroid than in other tissues. Absorbed SPD was extensively biotransformed with glutathione conjugating of $\mathrm{N}^{-}$or $\mathrm{O}^{-}$demethylated spinosyn $\mathrm{A}$ or $\mathrm{D}$ as the predominant metabolites ${ }^{4}$.

Spinosad would be safe to foraging worker bees, queen and brood when it is used according to the approved product label recommendations ${ }^{5}$. In rats, no toxicity was recorded at any supplemented dose. Moreover, there was no maternal toxicity at 10 or $50 \mathrm{mg} / \mathrm{kg} /$ day after administration of SPD by gavage to pregnant $\mathrm{CD}(\mathrm{R})$ rats ${ }^{6}$. Nevertheless, it was reported that SPD has toxicity toward other non-target organisms and some beneficial insects with rapid degradation in the environment 7,8. In insects, SPD's mode of action is associated with excitation of the insect nervous system ${ }^{2}$. In addition, vacuolization of rats' epithelial cells in numerous organs such as liver, lymphatic nodes, kidneys, stomach and lungs after SPD exposure was reported ${ }^{9}$. Therefore, the present study was conducted to assess the toxic effect of two sub-chronic doses, 35 and $350 \mathrm{mg} / \mathrm{kg}$ of SPD on some biochemical, histological and immunohistochemical parameters of the liver, kidney and cerebellum in male mice.

\section{MATERILAS AND METHODS}

\section{Chemicals}

A commercial SPD under the commercial name Tracer® comprising $480 \mathrm{~g} \mathrm{~L}^{-1}$ active ingredient (CAS No. 131929-60-7) was purchased from Dow AgroSciences LLC (Indianapolis, IN, USA). The rabbit monoclonal antibody of synaptophysin SYP (MRQ- 40) and DAB CM (3, 3'-diaminobenzidine) were purchased from Roche, Diagnositics Limited, Charles Avenue, Burgess Hill®.

\section{Experimental animals}

Thirty-six male albino mice weighing 26 to $28 \mathrm{~g}$. were obtained from the animal house of the college of Pharmacy, Aljouf University, Sakaka, King of Saudi Arabia (KSA). The mice were housed in steel mesh cages and maintained for 1 week for the acclimatization (clean and dry plastic cages in $12 \mathrm{~h}$ dark/light cycle under normal laboratory condition of temperature and humidity, fed with rodent pellets and tap water ad libitum. The animals were maintained in accordance with the U.S. National Institutes of Health Guide for the Care and Use of Laboratory Animals ${ }^{10}$. The protocol of the current experiment was approved by the Animal Care and Use Committee of Aljouf University, KSA.

\section{$\mathbf{L D}_{50}$ determination}

A total number of 28 adult male mice of eight weeks old $(25-27 \mathrm{~g})$ were divided into 7 groups of 4 mice each. These groups were injected with a single dose of 1,2 , $3,4,5,6$ and $7 \mathrm{~g} / \mathrm{kg}$ of SPD, respectively. SPD was dissolved in water ${ }^{11}$. Mice were noticed for $24 \mathrm{~h}$ to assess the acute toxicity of SPD. $\mathrm{LD}_{50}$ of SPD was 
calculated using the arithmetic method ${ }^{12}$. The formula is: $\mathrm{LD}_{50}=\mathrm{LDy}-\sum(\mathrm{Dd} \mathrm{x}$ $\mathrm{Md}) / \mathrm{N}$ Where: $\mathrm{LDy}=$ Highest dose $\left(\mathrm{LD}_{100}\right), \mathrm{N}=$ Number of animals per group, $\mathrm{Dd}$ $=$ Dose difference, $\mathrm{Md}=$ Mean dead.

\section{Experimental design}

Thirty-six male mice were randomly divided into 3 groups of 12 individuals each. The first group (G1) served as a control in which mice were received the same volume of water which SPD was dissolved in; the second group (G2) received a sub-chronic dose of SPD (35 mg/kg/day) that is equal to $1 / 100 \mathrm{LD}_{50}$. The third group (G3) received a sub-chronic dose of SPD (350 mg/kg/day) that is equal to $1 / 10 \mathrm{LD}_{50}$. The solutions were administered orally via gavage for consecutive 4 weeks. At the end of the experiment, mice were euthanized via inter-peritoneal injection with sodium pentobarbital $(100 \mathrm{mg} / \mathrm{kg})$ then subjected to complete dissection. Liver and spleen weights were determined.

\section{Estimation of biochemical parameters}

Blood samples were collected from the inferior vena cava in glass tubes. Serum was separated by centrifugation at $3000 \mathrm{rpm}$ for $15 \mathrm{~min}$. The enzymatic activities of alanine aminotransferase (ALT), aspartate aminotransferase (AST) were measured by commercial kits ${ }^{13}$. Total protein and albumin levels were estimated by Biuret method ${ }^{14}$. Urea levels were measured by coupled reactions described by Fawcett and Soctt ${ }^{15}$. Total triglycerides (TG) were assessed according to the commercial kits ${ }^{16}$.

\section{Determination of the histopathological and immunohistochemical changes}

Livers, kidneys and cerebella were immediately removed from the mice, sliced and fixed in Bouin's fixative for 2 to $4 \mathrm{~h}^{17}$. The specimens were then dehydrated, cleared and embedded in paraffin. Serial sections of $5 \mu \mathrm{m}$ thick were cut by rotary microtome and some were processed for hematoxylin and eosin staining ${ }^{18}$. Brain paraffin sections were deparaffinized in xylene, dehydrate in descending grades of alcohol and immersed in $0.3 \%$ hydrogen peroxide in methanol to block endogenous peroxidase activity then washed in phosphate buffered saline and incubated for 3-5 minutes in citrate buffer at $100 \mathrm{C}^{\circ}$ followed by washing in phosphate buffer. The sections then were incubated for $1 \mathrm{~h}$ in diluted monoclonal synaptophysin [SYP clone (MRQ-40)]. The sections were rinsed in biotinylated secondary antibody for 15 minutes followed by washing with phosphate buffer and Avidin-biotin for 15 min. The reaction was rinsed using DAB CM for 3 minutes as a red brown color then washed with running water. The sections were countered stained with Mayer's HX, hydrated in ascending grades of alcohol, cleared and mounted. All stained sections were examined and photographed using Optika light microscope (B-350).

\section{Statistical analysis}

Numerical data obtained from the experiment were expressed as mean \pm SD.

Statistical differences between experimental groups were assessed using one-way ANOVA. $P$ values less than 0.05 were considered to indicate statistical significance. All statistical analyses were performed using SPSS

\section{RESULTS}

The median lethal dose $\left(\mathrm{LD}_{50}\right)$ of SPD was determined in the present study as $3.5 \mathrm{~g}$ $\mathrm{kg}^{-1}$ (data not shown). At the level of the selected doses in this study (35 and 350 $\mathrm{mg} / \mathrm{kg}$ ), no untoward clinical signs were observed in the surviving mice. There were no changes in the nature of stool, urine and eye color of all animals. No mortality was observed in the different groups during the experiment. 


\begin{abstract}
Effect of administration of sub-chronic low and high doses of SPD on the body weight and relative weights of kidney, liver and spleen

The results showed that the mice of the second group which were received 35 $\mathrm{mg} / \mathrm{kg}$ SPD had a non-significant change ( $\mathrm{p}>0.05)$ in their body weights and the relative weights of the liver, kidney and spleen while the mice of the third group which were received $350 \mathrm{mg} / \mathrm{kg}$ SPD showed a significant change $(\mathrm{p} \leq 0.05)$ in their body weights and the relative weights of the kidney and spleen while showed a non-significant change $(p>0.05)$ in the relative body weight of the liver when compared with the mice in the control group, respectively. The mice of the third group showed also a significant change $(\mathrm{p} \leq 0.05)$ in their relative weights of the spleen when compared with the mice in the second group (Table 1).
\end{abstract}

Table 1: The total body weight and the relative body weights of the liver, kidney and spleen 4 weeks after treatment with two sub-chronic doses 35 and $350 \mathrm{mg} / \mathrm{kg}$ of SPD

\begin{tabular}{cccc}
\hline Parameters & $\begin{array}{c}\mathbf{1}^{\text {st }} \text { group } \\
\text { (Control) }\end{array}$ & $\begin{array}{c}\mathbf{2}^{\text {nd }} \text { group } \\
(\mathbf{3 5} \mathbf{~ m g / k g} \text { of } \mathbf{S P D})\end{array}$ & $\begin{array}{c}\mathbf{3}^{\text {rd }} \text { group } \\
\mathbf{( 3 5 0 ~} \mathbf{~ m g} / \mathbf{k g ~ o f ~ S P D )}\end{array}$ \\
\hline TBW & $29.81 \pm 2.47$ & $28.70 \pm 5.42$ & $27.57 \pm 4.31^{\mathrm{a}}$ \\
RLW (\%) & $5.47 \%$ & $5.78 \%$ & $5.48 \%$ \\
RKW (\%) & $0.6 \%$ & $0.7 \%$ & $0.74 \%^{\mathrm{a}}$ \\
RSW (\%) & $0.77 \%$ & $0.84 \%$ & $0.91 \%^{\mathrm{ab}}$ \\
\hline
\end{tabular}

Data are expressed as mean $\pm \mathrm{SD}, \mathrm{n}=12$. Total body weight (TBW), Relative liver weight (RLW), Relative kidney weight (RKW), Relative spleen weight (RSW). Relative organ weight $=$ (organ weight / body weight) $\mathrm{x} 100$ a: statistical difference from the control $\left(1^{\text {st }}\right)$ group- significant if $\mathrm{p} \leq 0.05$.

b: statistical difference from the $\left(2^{\text {nd }}\right)$ group- significant if $\mathrm{p} \leq 0.05$

Effect of administration of sub-chronic SPD low and high doses on the
biochemical parameters The present study showed that the mice which were received $35 \mathrm{mg} / \mathrm{kg}$ SPD showed a significant increase $(\mathrm{p} \leq 0.05)$ only in triglycerides and urea levels while the mice which were received $350 \mathrm{mg} / \mathrm{kg}$ SPD showed a significant increase $(\mathrm{p} \leq$ 0.05 ) in both of ALT, triglycerides and urea levels when compared with the mice in control group, respectively. In addition, the mice which were received $350 \mathrm{mg} / \mathrm{kg}$ SPD showed a significant increase $(\mathrm{p} \leq 0.05)$ in both of ALT and total protein when compared with the mice which were received $35 \mathrm{mg} / \mathrm{kg} \mathrm{SPD}$, respectively (Table 2).

Table (2): The biochemical parameters 4 weeks after treatment with two sub-chronic doses 35 and $350 \mathrm{mg} / \mathrm{kg}$ of SPD

\begin{tabular}{|c|c|c|c|}
\hline Parameters & $\begin{array}{l}\mathbf{1}^{\text {st }} \text { group } \\
\text { (Control) }\end{array}$ & $\begin{array}{c}2^{\text {nd }} \text { group } \\
(35 \mathrm{mg} / \mathrm{kg} \text { of SPD })\end{array}$ & $\begin{array}{c}3^{\text {rd }} \text { group } \\
(350 \mathrm{mg} / \mathrm{kg} \text { of } \mathrm{SPD})\end{array}$ \\
\hline A.L.T (U/L) & $27.25 \pm 3.69$ & $28.47 \pm 6.26$ & $30.6 \pm 5.66^{\mathrm{ab}}$ \\
\hline A.S.T (U/L) & $36.0 \pm 3.57$ & $36.87 \pm 2.17$ & $35.64 \pm 2.10$ \\
\hline Total protein $(\mathrm{g} / 100 \mathrm{ml})$ & $6.80 \pm 0.52$ & $6.7 \pm 0.47$ & $8.3 \pm 1.64^{\mathrm{ab}}$ \\
\hline Albumin $(\mathrm{g} / 100 \mathrm{ml})$ & $5.53 \pm 0.32$ & $5.82 \pm 0.26$ & $5.74 \pm 0.38$ \\
\hline Triglycerides $(\mathrm{mg} / 100 \mathrm{ml})$ & $277.16 \pm 35.64$ & $306.12 \pm 25.15^{\mathrm{a}}$ & $302.41 \pm 15.34^{\mathrm{a}}$ \\
\hline Urea $(\mathrm{mmol} / \mathrm{l})$ & $2.83 \pm 0.85$ & $3.33 \pm 0.44^{\mathrm{a}}$ & $3.95 \pm 1.54^{\mathrm{a}}$ \\
\hline
\end{tabular}

Data are expressed as mean $\pm \mathrm{SD}, \mathrm{n}=12$. Alanine aminotransferase ALT, aspartate aminotransferase (AST)

a: statistical difference from the control $\left(1^{\text {st }}\right)$ group- significant if $\mathrm{p} \leq 0.05$.

$\mathrm{b}$ : statistical difference from the $\left(2^{\text {nd }}\right)$ group- significant if $\mathrm{p} \leq 0.05$

Effect of administration of sub-chronic low and high doses of SPD on the liver cytoarchitecture 
Examination of the liver sections from the control group illustrated normal liver cytoarchitecture. The polyhedral hepatocytes arranged radially forming cords around the central vein (Fig. 1a). Liver sections from the mice which were received $35 \mathrm{mg} / \mathrm{kg}$ SPD showed mild histological changes. Disappearance of the regularly and radially arranged hepatocytes, aggregation of small patches of collagen fibers, detection of fainter stained hepatocytes and mild lymphocytic infiltration were observed (Figs. 1b, c). Meanwhile, liver sections of the mice which were received $350 \mathrm{mg} / \mathrm{kg}$ SPD showed extensive degeneration and necrosis of the hepatocytes. Fatty degeneration and detection of various inflammatory cells were also displayed (Fig. 1d).

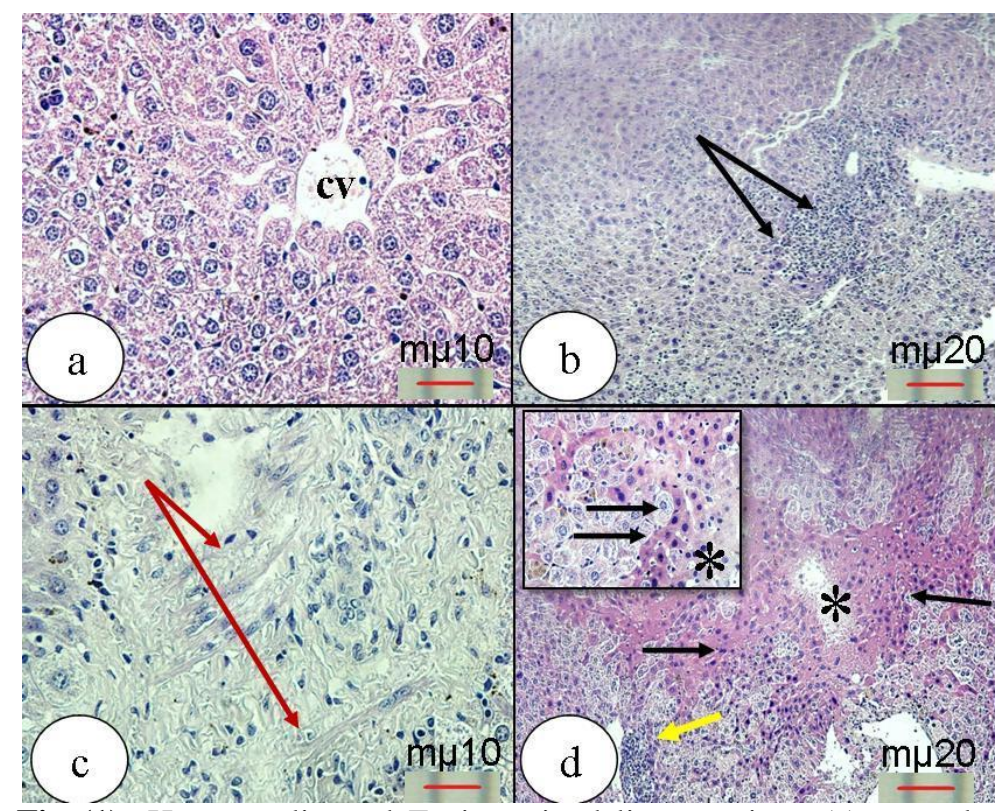

Fig (1): Hematoxylin and Eosin stained liver sections (a) control group showing radially arranged hepatocytes around the central vein (cv), (b, c) mice that were treated with $35 \mathrm{mg} / \mathrm{kg}$ SPD lymphocytic infiltration (black arrows), and aggregation of small bundles of the collagen fibers (red arrows), (c) mice that were treated with 350 $\mathrm{mg} / \mathrm{kg}$ SPD showing extensive degeneration (stars), necrotic hepatocytes (black arrows) and cellular infiltration

\section{Effect of administration of sub-chronic low and high doses of SPD on the kidney cytoarchitecture}

Examination of the kidney sections of the mice of the control group revealed normal cytoarchitecture. Well developed renal glomerulei which encapsulated with Bowman's capsule and normal proximal and distal convoluted tubules were determined (Fig. 2a). Examination of the kidney sections of the mice that were treated with $35 \mathrm{mg} / \mathrm{kg}$ SPD showed limited histopathological changes. Widening of the renal tubules, mild lymphocytic infiltration surrounding the damaged glomerulei, cytoplasmic vacuolation of the epithelial lining cells of the renal tubules were determined (Fig. 2b). Examination of the kidney sections of the mice that were treated with $350 \mathrm{mg} / \mathrm{kg}$ SPD showed severe lymphocytic infiltration, necrosis of the epithelial cells and nuclear pyknosis. In addition, some glomerulei were displayed hyperplasia and the cytoplasmic vacuolation of some epithelial lining cells were also determined (Figs. 2c, d). 


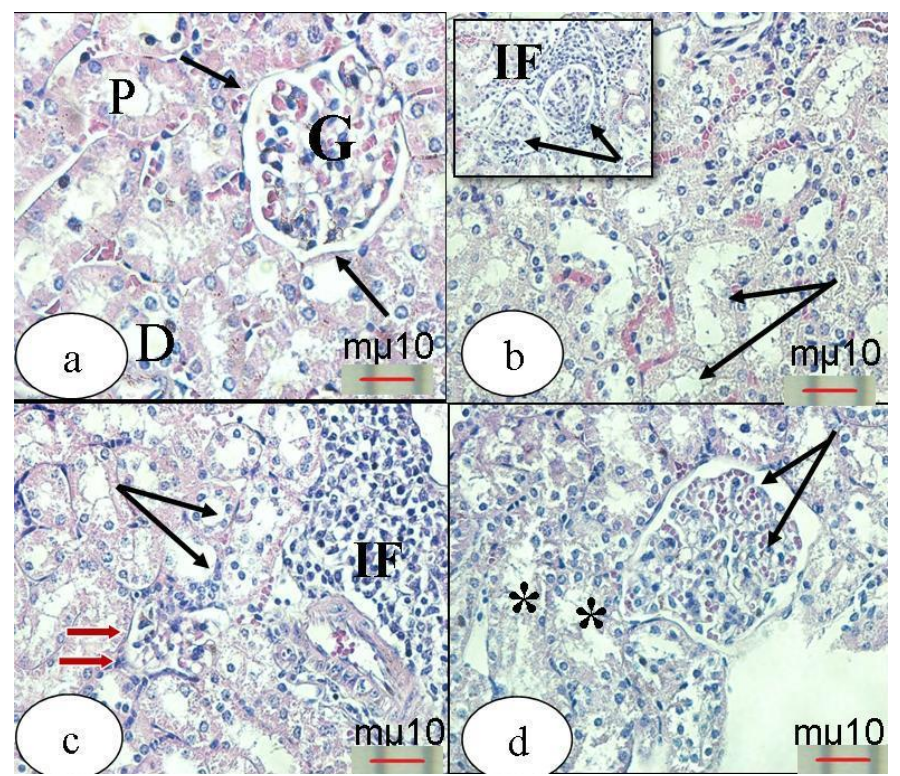

Fig (2): Hematoxylin and Eosin stained kidney sections. (a) control group showing Bowman's capsule (arrows) of the glomerulus $(\mathrm{G})$, proximal tubules (p) and distal tubules (D), (b) mice that were treated with $35 \mathrm{mg} / \mathrm{kg}$ SPD showing lymphocytic infiltration (IF) surrounding disorganized glomerulei (arrows) and degenerated and vacuolated epithelial necrotic cells (arrows), (c, d) mice that were treated with $350 \mathrm{mg} / \mathrm{kg}$ SPD (c) showing lymphocytic infiltration(IF), necrosis of the some renal epithelial cells (arrows) and nuclear pyknosis of other epithelial cells (red arrows), (d) showing hyperplasia of the glomerular cells (arrows) and extensive cytoplasmic vacuolation of the renal epithelial cells (stars).

Effect of administration of sub-chronic low and high doses of SPD on the brain cytoarchitecture

Examination of the cerebellum of the control mice showed a typical histological architecture which appeared as outer molecular layer, middle Purkinje cell layer and inner granular layer (Fig. 3a). Immunohistochemical stained sections with synaptophysin SYP (MRQ- 40) antibody indicated the expression of the synaptophysin protein in the synaptic vesicles at the synaptic sites as a marked strong positive dark brown coloration at both the molecular and the granular layers (Fig. 4a). Examination of the cerebellum sections of the mice that were treated with $35 \mathrm{mg} / \mathrm{kg}$ of SPD showed mild changes in its cytoarchitecture. Pale stained sections with non homogeneous granular layer and moderately stained Purkinje cells were detected (Fig. 3b). Immuohistochemical stained sections with synaptophysin SYP (MRQ- 40) antibody showed an expression level that less or more similar to what was observed in the control group (Fig. 4b). On the other hand, examination of the cerebellum sections of the mice that were treated with $350 \mathrm{mg} / \mathrm{kg}$ of SPD revealed necrotic Purkinje cells and nuclear pyknosis of the granular cells. In addition, non homogeneous neuropil was demonstrated (Figs. 3c, d). Immunohistochemical stained sections with synaptophysin SYP (MRQ- 40) antibody showed weakness of the reaction compared with the control group (Fig. $4 c)$. 


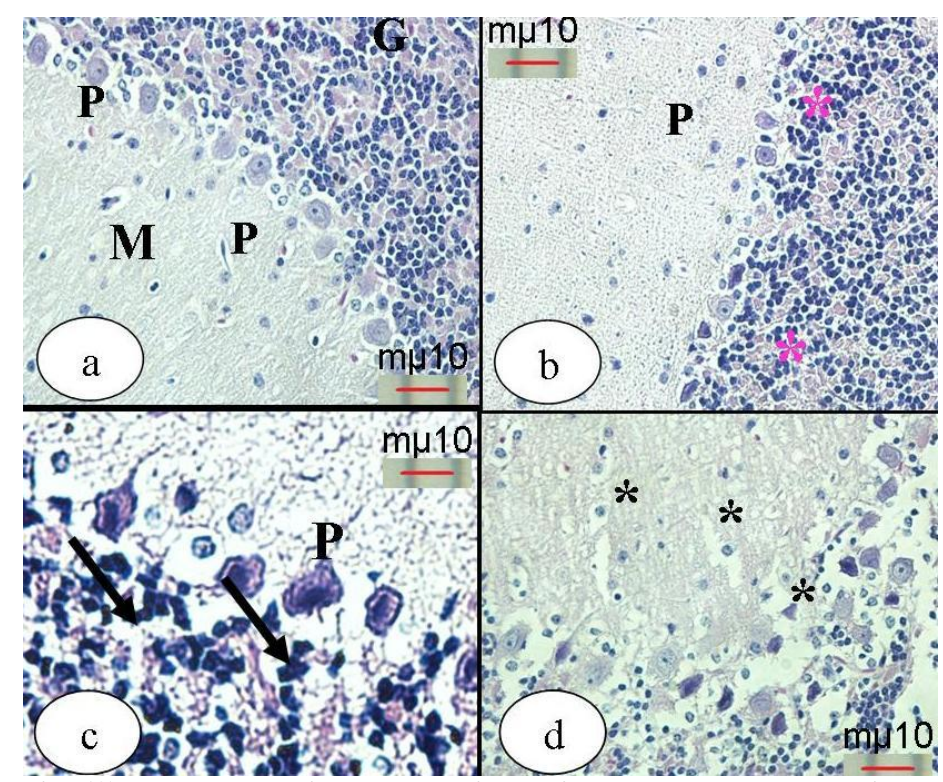

Fig (3): Hematoxylin and Eosin stained cerebellum sections. (a) control group showing the outer molecular layer (M), middle flasked shape Purkinje cell layer (P) and inner granular layer $(\mathrm{G})$, (b) mice that were treated with $35 \mathrm{mg} / \mathrm{kg}$ SPD showing pale stained section of the cerebellum with non homogeneous neuropil of the granular layer (stars) and moderately stained purkinje cell (P), (c, d) mice that were treated with $350 \mathrm{mg} / \mathrm{kg}$ SPD showing necrotic purkinje cell (P), nuclear pyknosis of the granular cells (arrows) and degeneration of the neuropil of the molecular layer (stars).
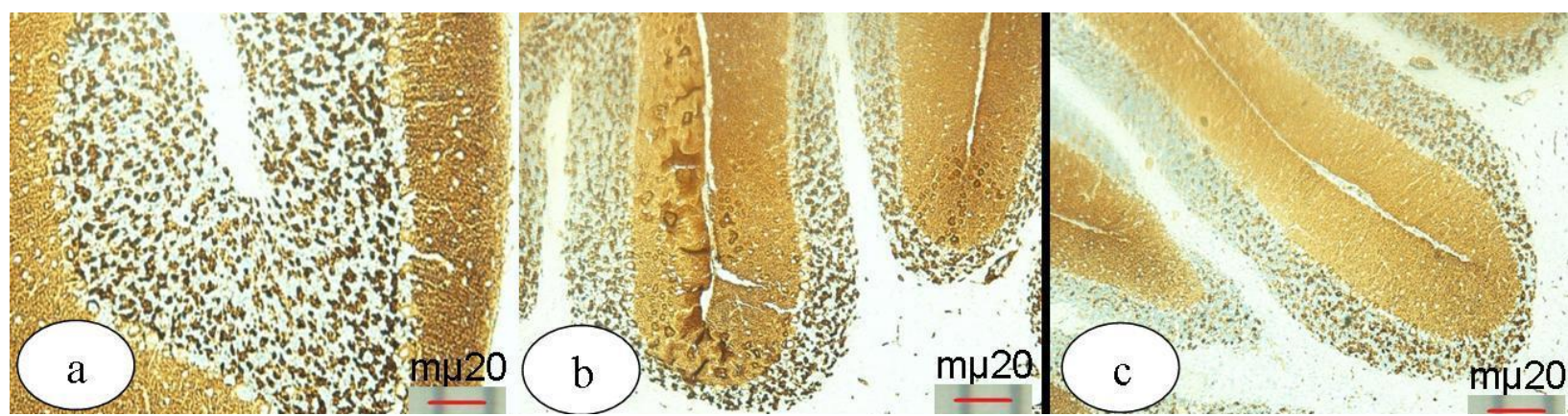

Fig. (4): Cerebellum sections immunohistochemically stained with synaptophysin antibody. (a) control group, (b) mice that were treated with $35 \mathrm{mg}$ SPD showing less stain ability, (c) mice that were treated with $350 \mathrm{mg} / \mathrm{kg}$ SPD showing less stain ability than in $35 \mathrm{mg} / \mathrm{kg}$ of SPD group.

\section{DISCUSSION}

The present study was conducted to assess the toxic effect of sub-chronic low and high doses of bio-insecticide, Spinosad (SPD), on the liver, kidney and cerebellum in male albino mice. The acute oral $\mathrm{LD}_{50}$ of SPD for mice in the current study was approximately $3500 \mathrm{mg} / \mathrm{Kg}$. Our finding was in agreement with the previous study which showed that the acute oral $\mathrm{LD}_{50}$ of SPD for rat was ranged from 3738 to $45000 \mathrm{mg} / \mathrm{kg}$ body weight ${ }^{19}$. According to Eaton and Klaassen ${ }^{20}$, the sub-chronic toxicity refers to the toxic effects that occur between 30 days and ninety days exposure. The results showed that the mice which were received $35 \mathrm{mg} / \mathrm{kg} \mathrm{SPD}$ had a non-significant change in their body weights and the relative weights of the liver, kidney and spleen while the mice were received $350 \mathrm{mg} / \mathrm{kg}$ SPD showed a significant decrease in their body weights and a significant increase in the relative weights of the kidney and spleen comparing with the control mice, respectively. This finding was in agreement with Yano et al. ${ }^{19}$ who found that the body weights 
of the rats which were given more than $0.2 \%$ SPD were significantly lower than the control rats. The same finding was reported by Breslin et al. ${ }^{6}$ in rabbits.

In the present study, ALT, AST, total protein, albumin, triglycerides and urea levels were assessed after treatment with 35 and $350 \mathrm{mg} / \mathrm{kg}$ SPD for consecutive 4 weeks, respectively. The results showed that treatment with $35 \mathrm{mg} / \mathrm{kg}$ SPD showed a significant increase in only triglycerides and urea levels while treatment with 350 $\mathrm{mg} / \mathrm{kg}$ SPD showed a significant increase in both of ALT, triglycerides, and urea levels. This result was in agreement with Yano et al. ${ }^{19}$ who reported that rats which were given 0.1 or $0.2 \%$ SPD had a minor increase in AST, ALT, urea, nitrogen, cholesterol, and triglyceride levels. On the other side, Stebbins et al. ${ }^{21}$ found that mice which were given $0.12 \%$ SPD had a remarkable increase in ALT and AST enzyme activities. In fact, the commonest enzymes in the diagnosis of hepatocellular damage are the transaminase enzymes which include AST and ALT ${ }^{22-24}$. The increase in their activities is roughly proportional to the extent of the tissue damage T5-28. $^{25}$.

The histological findings of the present study revealed lymphocytic infiltration, hyperplasia and cytoplasmic vacuolation of the hepatocytes and renal epithelial cells after exposure to $350 \mathrm{mg} / \mathrm{kg}$ SPD. This finding was in consistent with our biochemical results which reported the increase of ALT after the exposure to the same dose. Therefore, we could conclude that $350 \mathrm{mg} / \mathrm{kg}$ of SPD has a toxic effect on the hepatocytes. Aboul-Enein et al. reported that the toxic effect of SPD on hepatocytes is mediated primarily through the formation of ROS. ROS generation can affect cell activity and function including DNA damage and nuclear pyknosis 9 . It can also have diverse effects on mammalian cell growth and even small quantities are capable of directing cells to undergo apoptosis or necrosis ${ }^{29,30}$. In addition, the detection of lymphocyte infiltration in the liver and kidney tissues may be explained as it is a result of a toxic chemical resistance from the animal body. This may be due to the activation of the defense mechanism and the immune system within the body ${ }^{19}$. The toxicity of several compounds including insecticides generates auto-antibodies due to their interference with the immune system ${ }^{31}$. Several studies reported that SPD belongs and similar to cationic amphilic drugs $\left(\mathrm{CAD}_{\mathrm{s}}\right)$ in their action mechanism ${ }^{32,33}$. The principal exposure to $\mathrm{CAD}_{\mathrm{S}}$ results in many histopathological changes such as cytoplasmic vacuolation, damage of the membranous structure in the cells.

In our study, we selected the cerebellum as a representative tissue for the central nervous system (CNS). The cerebellum is a region of the brain that plays an important role in motor control. Also, it may be involved in some cognitive functions such as attention and language. The cerebellum does not initiate movement, but it contributes to coordination, precision, and accurate timing ${ }^{34}$. So, it reflects the CNS integrity and can test if the SPD had side effects on the nervous tissue or causes any neurohistopathological features on the cerebellum. In the present study, the immunohistochemical staining with synaptophysin was used for demonstration the synaptic sites in the cerebellum because the synaptic sites could not appear with the regular stain with Hematoxylin and Eosin. The study recorded several neurodegenerative changes as necrosis of Purkinje cells of the cerebellum after treatment with $350 \mathrm{mg} / \mathrm{kg}$ of SPD. The molecular and granular nerve cell layer showed non-homogeneous distribution. As further, the expression of the synatophysin protein at the synaptic sites in the cerebellar tissue were depleted and appeared fainter than in the control sections. Some of these finding were in consistence with several previous studies ${ }^{9,11}$. Interestingly, the results of the current study was not in consistence with WHO's report which mentioned that SPD has no effect on the nervous system of either human or animals ${ }^{4}$. 
The mode of action of SPD is characterized by an excitation of the nervous system with activation of nicotinic acetylcholine receptors $\left(n A c h R_{S}\right)$ along with effects on $\gamma$ - amino butyric acid (GABA) receptor function and GABA-gated chloride channels and can elicit a small-amplitude $\mathrm{cl}^{-}$current ${ }^{2}$. In support of this, SPD's chemical structure (a hydrophobic ring structure with a hydrophilic side-chain containing a basic amine group) is comparable to other cationic amphiphilic drugs which produce similar cellular toxicity ${ }^{3}$. Aboul-Enein et al. reported that AchE enzyme activity was inhibited, as a result of the sub-chronic exposure of rats to SPD at $1 / 20$ of $\mathrm{LD}_{50}$ for 4 weeks ${ }^{9}$. It was found that inhibition of the AchE results in accumulation of acetylcholine (Ach) at cholinergic synapses to toxic levels leading to over-stimulation of muscarinic and nicotinic receptors. This cholinergic syndrome includes signs and symptoms such as greater sweating and salivation, bronchycardia, loss of reflexes, generalized convulsions, coma and central respiratory paralysis ${ }^{35}$. Eshkind and Leube reported that synaptophysis reconstituted into lipid bilayers induces the formation of voltage-sensitive channels

${ }^{36}$. Furthermore, it was found that there is a correlation between synaptophysin and synaptobrevin, a component of the vesicle docking complex, and can be taken as another indication for the involvement of synaptophysin in regulated vesicles exocytosis. So, the synaptophysin is important for vesicle formation of synapses ${ }^{37}$.

\section{CONCLUSION}

Exposure to the high dose of SPD that is equal to $350 \mathrm{mg} / \mathrm{kg}$ showed a marked toxicity on the liver, kidney and cerebellum in male albino mice.

\section{ACKNOWLEDGMENT}

The authors wish to thank the research unit at the Faculty of Science, University of Dammam and Biology Department, Faculty of Science, Aljouf University for supporting and providing the facilities to accomplish the practical work and photographing the tissue sections of the study.

\section{REFERENCES}

1- Mertz FP, Yao RC. Saccharopolyspora spinosa sp. nov. isolated from soil collected in a sugar rum still. Int J Syst Evol Micr. 1990; 40: 34-39.

2- $\quad$ Salgado VL. Studies on the mode of action of spinosad: Insect symptoms and physiological correlates. Pestic Biochem Phys. 1998; 60: 91-102.

3- Halliwell WH. Cationic amphiphilic drug-induced phospho-lipidosis. Toxicol Pathol. 1997; 25: 53-60.

4- WHO. Spinosad DT in Drinking-water: Use for vector control in drinking-water sources and containers. Background document for development of WHO guidelines for drinking-water quality. Geneva (CWorld Health Organization, 2010

5- $\quad$ Mark M. The effects of spinosad, a naturally derived insect control agent to the honeybee. B Insect. 2003; 56: 119-124.

6- Breslin WJ, Marty MS, Vedula U, Liberacki AB, Yano BL. Developmental toxicity of spinosad administered by gavage to $\mathrm{CD} \circledast$ rats and $\mathrm{New}$ Zealand White rabbits. Food Chem Toxicol. 2000; 38: 1103-1112.

7- $\quad$ Kirst HA, Michel KH, Mynderse JS, Chio EH, Yao RC, Walter M, et al. Discovery, isolation, and structure elucidation of a family of structurally unique, fermentation-derived tetracyclic macrolides. In synthesis and chemistry of 
agrochemicals III (D. R. Baker, J. G. Fenyes, and J. J. Steffans, Eds.). American Chemical Society, Washington, DC, 1992; pp. 214-25.

8- Kirst HA. The spinosyns family of insecticides: realizing the potential natural products research. J Antibiot. 2010; 63: 101-111.

9- $\quad$ Aboul-Enein AM, Aboul-Soud MA, Said HK, Ali HF, Ali ZY, Mahdi $\mathrm{AM}$, et al. Hepato-protective effects of antioxidants against non-target toxicity of the bio-insecticide spinosad in rats. Afr J Pharm Pharmac. 2012; 6: 550-559.

10- National Institute of Health, USA. Public health service policy on human care and use of laboratory animals, 2002

11- Mansour AS, Mossa HA, Heikal TM. Cytogenetic and hormonal alteration in rats exposed to recommended "safe Doses" of spinosad and malathion insecticides. Int J Agr Biol. 2008; 10: 9-14.

12- Aliu YO, Nwude N. Veterinary pharmacology and toxicology experiments. A.B.U. Press: Zaria, 1982; 104-110.

13- Reitman S, Frankel S. A colorimetric method for the determination of serum glutamic oxalacetic and glutamic pyruvic transaminases. Am J Clin Pathol. 1957; 28: 56-63.

14- Itzhaki RF, Gil DM. A micro-biuret method for estimating proteins. Anal Biochem. 1964; 9: 401-410.

15- $\quad$ Fawcett JK, Scott JE. A rapid and precise method for the determination of urea. J Clin Pathol. 1960; 13: 156-159.

16- Fossati P, Lorenzo P. Serum triglycerides determined colorimetrically with an enzyme that produces hydrogenperoxide. Clin Chem. 1982; 28: 2077 2080.

17- Carson FL, Hladik C. Histotechnology: A Self-Instructional Text (3 ed.). Hong Kong: American Society for Clinical Pathology Press, 2009.

18- Bancroft JD, Stevens A. Theory and practical of histological techniques. 4th ed., Churchill Livingstone, New York. Edinburg and London, 1996.

19- $\quad$ Yano BL, Bond DM, Novilla MN, McFadden LG, Reasor MJ. Spinosad insecticide: Subchronic and chronic toxicity and lack of carcinogenicity in Fischer 344 Rats. Toxicol Sci. 2002; 65: 288-298.

20- Eaton DL, Klaassen CD. Principles of toxicology, in Klassen CD (ed) Casarett and Doull's Toxicology: The Basic Science of Poisons. $6^{\text {th }}$ Edition. McGraw-Hill Medical Publishing Division, 2001.

21- Stebbins KE, Bond DM, Novilla MN, Reasor MJ. Spinosad insecticide: subchronic and chronic toxicity and lack of carcinogenicity in CD-1 mice. Toxicol Sci. 2002; 65: 276-287.

22- $\quad$ Nnodim JK, Emejulu A, Amaechi A, Chukwunyere NE. Alterations in biochemical parameters of Wistar rats administered with sulfadoxine and pyrimethamine (Fansidar). Al Ameen J Med Sci. 2010; 3: 317-321.

23- Tousson E, Alm-Eldeen A, El-Moghazy M. p53 and Bcl-2expression in response to boldenone induced liver cells injury. Toxicol Ind Health. 2011; 27:711718.

24- Alm-Eldeen AA, Mona MH, Shati AA, El-Mekkawy HI. Synergistic effect of black tea and curcumin in improving the hepatotoxicity induced by aflatoxin B1 in rats. Toxicol Ind Health. 2015; 31: 1269- 1280.

25- $\quad$ Ekam VS, Ebong PE. Serum protein and enzyme levels in rats following administration of antioxidant vitamins during caffeinated and non-caffeinated paracetamol induced hypatoxicity. Niger J Physiol Sci. 2007; 22: 65-68.

26- Ogbonnia S, Adekunle AA, Bosa MK, Enwuru VN. Evaluation of acute and subacute toxicity of Alstonia congensis Engler (Apocynaceae) bark and Xylopia aethiopca (Dunal) A. Rich (Annonaceae) fruits mixtures used in treatments of diabetes. Afr J Biotechnol. 2008; 7: 701-705. 
27- Nwaehujor CO, Ode OJ, Okoyie DN. The hepatoprotective effect of Senna occidentalis methanol leaf extract against acetaminophen induced hepatic damage in rats. J Pharm Toxicol. 2011; 6: 637-646.

28- El-Naggar SA, Alm-Eldeen AA, Germoush MO, El-Boray KF, Elgebaly HA. Ameliorative effect of propolis against cyclophosphamide-induced toxicity in mice. Pharm Biol. 2015; 53: 235- 241.

29- Ray SD, Kumar A, Bagchi D. A novel proanthocyanidin IH636 extract increases in vivo bcl-XL expression and prevents acetaminophen-induced programmed and unprogrammed cell death in mouse liver. Arch Biochem Biophys. 1999; 369: 42-58.

30- Finkel T, Holbrook NJ. Oxidants, oxidative stress and the biology of aging. Nature. 2000; 408: 239-247.

31- Mansour AS, Mossa HA, Heikal TM. Haematoxicity of a new natural insecticide "spinosad" on male albino rats. Int J Agr Biol. 2007; 2: 342-346.

32- Reasor MJ. A review of the biology and toxicologic implications of the induction of lysosomal lamellar bodies by drugs. Toxicol Appl Pharm. 1989; 97: 47-56.

33- $\quad$ Schneider P. Drug-induced lysosomal disorders in laboratory animals: New substances acting on lysosomes. Arch Toxicol. 1992; 66: 23-33.

34- Byrne JH. Neuroscience online: An electronic textbook for the neurosciences. Houston, Texas: Department of Neurobiology and Anatomy at The University of Texas Medical School, 1997.

35- Lassiter TL, Marshall RS, Jackson LC, Hunter DL, Vu JT, Padilla S. Automated measurement of acetylcholinesterase activity in rat peripheral tissues. Toxicology. 2003; 186: 241-253.

36- $\quad$ Eshkind LG, Leube RE. Mice lacking synaptophysin reproduce and form typical synaptic vesicles. Cell Tissue Res. 1995; 282: 423-433.

37- El-Tantawi GH, EL Namshan MM. Monosodium glutamate followed by barley in mice: A histological, immunohistochemical and ultrastructural approach. Egypt J Exp Biol. 2015; 11, 81-93. 